\title{
Safety and Efficacy of Sovateltide (IRL-1620) in a Multicenter Randomized Controlled Clinical Trial in Patients with Acute Cerebral Ischemic Stroke
}

\author{
Anil Gulati $^{1,2}$ (1) Nilesh Agrawal ${ }^{3} \cdot$ Deepti Vibha $^{4}$ - U. K. Misra ${ }^{5} \cdot$ Birinder Paul $^{6} \cdot$ Dinesh Jain $^{6} \cdot$ Jeyaraj Pandian $^{7}$. \\ Rupam Borgohain ${ }^{8}$
}

Accepted: 5 December 2020 / Published online: 11 January 2021

(c) The Author(s) 2021

\begin{abstract}
Background Sovateltide (IRL-1620, PMZ-1620), an endothelin-B receptor agonist, has been previously shown to increase cerebral blood flow, have anti-apoptotic activity and produce neurovascular remodeling when administered intravenously following acute cerebral ischemic stroke in rats. Its safety and tolerability were confirmed in healthy human volunteers (CTRI/2016/11/007509).

Objective Our objective was to determine the safety, tolerability and efficacy of sovateltide as an addition to standard of care (SOC) in patients with acute cerebral ischemic stroke.

Methods A prospective, multicentric, randomized, double-blind, placebo-controlled study was conducted to compare the safety (primary objective) and efficacy (secondary objective) of sovateltide in patients with acute cerebral ischemic stroke. Adult males or females aged 18-70 years who had experienced a radiologically confirmed ischemic stroke within the last 24 $\mathrm{h}$ were included in the study. Patients with intracranial hemorrhage and those receiving endovascular therapy were excluded. Patients randomized to the sovateltide group received three doses of sovateltide (each dose $0.3 \mu \mathrm{g} / \mathrm{kg}$ ) administered as an intravenous bolus over $1 \mathrm{~min}$ at an interval of $3 \pm 1 \mathrm{~h}$ on day 1 , day 3 and day 6 (total dose of $0.9 \mu \mathrm{g} / \mathrm{kg} / \mathrm{day}$ ). Patients randomized to the placebo group received an equal volume of saline. Every patient in both groups received SOC for stroke. Efficacy was evaluated using neurological outcomes based on National Institute of Health Stroke Scale (NIHSS), modified Rankin Scale (mRS) and Barthel Index (BI) scores from day 1 through day 90. Quality of life was measured using the EuroQoL-5 Dimensions (EQ-5D) and Stroke-Specific Quality of Life (SSQoL) at 60 and 90 days of follow-up.

Results A total of 40 patients with acute cerebral ischemic stroke were enrolled in this study, of whom 36 completed the 90-day follow-up. Patients received saline ( $n=18 ; 11$ male and 7 female) or sovateltide $(n=18 ; 15$ male and 3 female) within $24 \mathrm{~h}$ of onset of stroke. The number of patients receiving investigational drug within $20 \mathrm{~h}$ of onset of stroke was 14/18 in the saline group and 10/18 in the sovateltide group. The baseline characteristics and SOC in both cohorts was similar. Sovateltide was well-tolerated, and all patients received complete treatment with no incidence of drug-related adverse events. Hemodynamic, biochemical or hematological parameters were not affected by sovateltide. Sovateltide treatment resulted in improved mRS and BI scores on day 6 compared with day $1(p<0.0001)$, an effect not seen in the saline group. Sovateltide increased the frequency of favorable outcomes at 3 months. An improvement of $\geq 2$ points on the mRS was observed in 60 and $40 \%$ of patients in the sovateltide and saline groups, respectively ( $p=0.0519$; odds ratio [OR] 5.25). An improvement on the BI of $\geq 40$ points was seen in 64 and $36 \%$ of the sovateltide and saline groups, respectively ( $p=0.0112$; OR 12.44). An improvement of $\geq 6$ points on the NIHSS was seen in $56 \%$ of patients in the sovateltide group versus $43 \%$ in the saline group ( $p=0.2714$; OR 2.275). The number of patients with complete recovery (defined as an NIHSS score of 0 and a BI of 100) was significantly greater $(p<0.05)$ in the sovateltide group than in the saline group. An assessment of complete recovery using an $\mathrm{mRS}$ score of 0 did not show a statistically significant difference between the treatment groups. Sovateltide treatment resulted in improved quality of life as measured by the EQ-5D and SSQoL on day 90.

Conclusion Sovateltide was safe and well-tolerated and resulted in improved neurological outcomes in patients with acute cerebral ischemic stroke 90 days post-treatment.

Trial Registration The study is registered at CTRI/2017/11/010654 and NCT04046484.
\end{abstract}

Extended author information available on the last page of the article 


\section{Key Points}

A phase II trial was conducted to evaluate the safety, tolerability and efficacy of sovateltide, an endothelin B receptor agonist, in patients with acute cerebral ischemic stroke.

Sovateltide was administered in three doses, each $0.3 \mu \mathrm{g} /$ $\mathrm{kg}$, as an intravenous bolus over $1 \mathrm{~min}$ at an interval of 3 $\pm 1 \mathrm{~h}$ on day 1 , day 3 and day 6 (total dose/day: $0.9 \mu \mathrm{g} /$ $\mathrm{kg}$ ) post randomization.

Sovateltide was safe and well-tolerated. No adverse events were reported.

Significantly more patients in the sovateltide group had an improved Barthel Index (BI) score of $\geq 40$ points at 90 days of follow up (64 vs. $36 \%$ in the control group).

The number of patients showing a favorable improvement in modified Rankin Scale (mRS) (change of $\geq$ 2 points vs. baseline) and National Institute of Health Stroke Scale (NIHSS) (change of $\geq 6$ points vs. baseline) at 90 days was numerically but not statistically significantly greater (at a 95\% confidence level) in the sovateltide group ( 60 vs. $40 \%$ in the control group; 56 vs. $43 \%$ in the control group, respectively).

The sovateltide group had significantly more patients with an NIHSS score of 0 and a BI score of 100 , indicating that sovateltide increased the frequency of complete recovery compared with patients in the control group. The sovateltide group also had more patients with an mRS score of 0 , although this was not statistically significant.

\section{Introduction}

Stroke is the fifth most common cause of death in the USA and is also an important cause of serious long-lasting disability. Ischemic stroke caused by arterial occlusion is responsible for most strokes [1]. The currently available treatment for acute cerebral ischemic stroke includes tissue plasminogen activator (tPA) and mechanical thrombectomy. However, the use of tPA is limited to a short time window of $<4.5 \mathrm{~h}$ from the onset of symptoms [2], and it also has a $4.9 \%$ risk of intracranial hemorrhage [3]. Mechanical thrombectomy was limited to $6 \mathrm{~h}$ after onset of stroke symptoms but has recently been extended up to $24 \mathrm{~h}$ [4]. Limitations of time, risk of bleeding and involvement of larger blood vessels for thrombectomy restricts current treatment to only about $5 \%$ of patients. New effective drugs for acute cerebral ischemic stroke to alleviate neurological deficits and repair cerebral damage are urgently required. Significant effort is being made to understand the complex pathophysiology of stroke, and various mechanisms are being explored, including anticoagulation, neuroprotection and neuroregeneration [5-8]. Despite many encouraging preclinical results, numerous potential neurovascular protectants failed to demonstrate beneficial effects in clinical trials $[6,9]$. The reason for these failures could be the complex pathophysiology of ischemic stroke, which involves hypoxia, vascular damage, inflammation, apoptosis and other events leading to neural cell damage and functional impairment of the brain. Therefore, a new approach is needed with the potential to preserve salvageable brain tissue, minimize complications, and act as secondary prevention.

Endothelin-1 (ET-1) levels have been reported to be elevated in the blood and brain tissues following cerebral ischemia $[10,11]$. Since ET-1 has been described as a potent vasoconstrictor acting via endothelin $\mathrm{A}\left(\mathrm{ET}_{\mathrm{A}}\right)$ receptors, it was hypothesized that $\mathrm{ET}_{\mathrm{A}}$ receptor antagonists would reduce the damage associated with acute cerebral ischemic stroke. Studies focused on antagonizing $\mathrm{ET}_{\mathrm{A}}$ receptors using BQ123, SB234551, A-127722 and S-1039 demonstrated a reduction in infarct area, edema, and neurological deficits following experimental cerebral ischemia [12-16], but these drugs have not advanced to clinical testing. Combined $\mathrm{ET}_{\mathrm{A} / \mathrm{B}}$ receptor antagonists have shown mixed results: TAK-044 decreased oxidative stress and reduced ischemia, whereas bosentan and SB209670 had no effect in animal models of acute ischemic stroke $[17,18]$. Conversely, antagonizing endothelin $\mathrm{B}\left(\mathrm{ET}_{\mathrm{B}}\right)$ receptors worsened ischemic injury, leading to poor outcomes [19, 20], suggesting a critical role of $\mathrm{ET}_{\mathrm{B}}$ receptors in salvaging brain damage due to cerebral ischemia.

$\mathrm{ET}_{\mathrm{B}}$ receptors are present in large numbers in the central nervous system (CNS) and play a key role in its development. We have demonstrated that $\mathrm{ET}_{\mathrm{B}}$ receptors in the brain are over expressed at the time of birth and that their expression decreases as the brain matures [21,22], suggesting that they are important in brain development and may be useful in the repair and regeneration of adult brains after stroke $[5,23,24] . \mathrm{ET}_{\mathrm{B}}$ receptors play an important role in neural cell survival and proliferation [5, 25-28]. Stimulation of $\mathrm{ET}_{\mathrm{B}}$ receptors in middle cerebral artery-occluded rats with intravenous administration of sovateltide, a highly selective $\mathrm{ET}_{\mathrm{B}}$ receptor agonist, significantly improved neurological and motor functions; decreased infarct volume, oxidative stress and apoptotic damage; and increased cell proliferation and angiogenesis $[24,29,30]$. Sovateltideinduced improvements were blocked with the $\mathrm{ET}_{\mathrm{B}}$ receptor antagonist $\mathrm{BQ788}$, confirming $\mathrm{ET}_{\mathrm{B}}$ receptor involvement in sovateltide effects $[29,30]$. 
Sovateltide demonstrated potential to be a novel and effective drug to treat acute cerebral ischemic stroke. The safety and tolerability of sovateltide was demonstrated in a clinical (CTRI/2016/11/007509) phase I study in healthy human volunteers [5]. The aim of the present study was to investigate the effect of sovateltide in adult patients who had experienced a cerebral ischemic stroke.

\section{Methods}

This was a prospective, multicenter, randomized, placebocontrolled, double-blinded, exploratory phase II clinical study to evaluate the safety and efficacy of sovateltide as an addition to standard of care (SOC) in patients with acute ischemic stroke. The primary objective was to evaluate the safety and tolerability of sovateltide. Key secondary objectives included measurement of efficacy (i.e., neurological improvements) using the National Institute of Health Stroke Scale (NIHSS), the modified Rankin Scale (mRS) and the Barthel Index (BI), and quality-of-life assessments using the EuroQol-5 Dimensions (EQ-5D) and Stroke-Specific Quality of Life (SSQoL).

\subsection{Patients, Eligibility Criteria and Trial Design}

Key inclusion criteria were as follows: age 18-70 years, patient presenting up to $24 \mathrm{~h}$ after onset of stroke symptoms with an mRS score of 3-4 and NIHSS score of 5-14, stroke is ischemic in origin, and supratentorial and radiologic confirmation with either a computed tomography scan or diagnostic magnetic resonance imaging. Female patients were either not of child-bearing potential or using two methods of contraception. Key exclusion criteria included the following: patients receiving endovascular therapy, intracranial hemorrhage, recurrent stroke, participation in other therapeutic clinical trials, evidence of major life-threatening or serious medical condition, pregnant or breast-feeding women or a positive pregnancy test.

The study was conducted in accordance with the International Conference on Harmonisation of Technical Requirements for Registration of Pharmaceuticals for Human Use Guideline for Good Clinical Practice (ICH-GCP), the principles of the Declaration of Helsinki and local regulatory requirements. The study protocol (PMZ-01 version 2.0/April 18, 2016) was approved by the Drugs Controller General of India, Directorate General of Health Services, Ministry of Health and Family Welfare, Government of India, and the institutional ethics committee for each of the seven sites (who reviewed and approved the study protocol before patient enrolment at each site was initiated). The study was registered at the Clinical Trials Registry, India (CTRI/2017/11/010654), and the US National Library of
Medicine, ClinicalTrials.gov (NCT04046484). The ethics committee for each site was continuously informed of any protocol deviation, amendment, subject exclusion or withdrawal and serious adverse events. Informed consent was obtained from each patient; if a patient was not fit to give consent themselves at the time of treatment initiation, informed consent was provided by their legally authorized representative (LAR).

\subsection{Treatment Regimen}

Patients were randomized 1:1 to either sovateltide or saline placebo. Block randomization was used for patient randomization into the two treatment groups. The randomization list was prepared by a statistician using a validated computer program, the statistical analysis system SPSS. An interactive web response system (IWRS) method containing randomization codes was used to randomize eligible patients to the treatment groups.

All patients in both groups received SOC for ischemic stroke according to their local institutional guidelines. Sovateltide was administered as an add-on to SOC. SOC was provided to patients according to the particular hospital setup and each patient's medical condition. Patients in the sovateltide group received three doses of sovateltide (each dose $0.3 \mu \mathrm{g} / \mathrm{kg}$ ) administered as an intravenous bolus over $1 \mathrm{~min}$ at an interval of $3 \pm 1 \mathrm{~h}$ on day 1 , day 3 and day 6 (total dose of $0.9 \mu \mathrm{g} / \mathrm{kg} / \mathrm{day}$ ). Specific intravenous treatments over 3 days post stroke was based on preclinical proof-ofconcept studies conducted in our laboratory $[24,25,29,30]$. The dose of sovateltide used in efficacy studies in rats was $5 \mu \mathrm{g} / \mathrm{kg}$ intravenously, and the human equivalent dose was calculated as $0.80 \mu \mathrm{g} / \mathrm{kg}$. In phase I safety and tolerability studies, the minimum intolerable dose for sovateltide was $0.9 \mu \mathrm{g} / \mathrm{kg}$ and the maximum tolerated dose was $0.6 \mu \mathrm{g} / \mathrm{kg}$ [5]. Patients in the placebo group received an equal volume of saline as an intravenous bolus over $1 \mathrm{~min}$ at an interval of $3 \pm 1 \mathrm{~h}$ on day 1 , day 3 and day 6 . The study duration for each patient was 3 months (90 days), which included five study visits: visit 1 (day 1-6, screening/baseline measurements/treatment/assessment), visit 2 (day 12, assessment), visit 3 (day $30 \pm 5$ days, assessment), visit 4 (day $60 \pm 5$ days, assessment) and visit 5/end of study (day $90 \pm 5$ days, assessment). All patients were monitored closely throughout hospitalization for qualifying stroke and followed-up for 90 days from randomization.

\subsection{Data Safety Monitoring Board}

An independent data safety monitoring board consisting of a neurologist, a biostatistician, and a clinical pharmacologist was established to monitor the safety and efficacy of the trial. The data safety monitoring board reviewed the safety 
data of each subject from the study and all serious adverse events, regardless of attribution, contemporaneously with submissions to the sponsor and investigator.

\subsection{Safety and Tolerability Assessments}

All patients who received treatment were included in the safety analysis. Safety was assessed during treatment and the post-treatment follow-up period based on adverse events, physical examination, vital signs and clinical laboratory parameters as per protocol. A complete set of hematological, biochemical and organ function tests (complete blood count, blood glucose, lipid profile, serum electrolytes, liver function test and kidney function test) were performed. Adverse events that occurred or worsened during treatment or posttreatment were recorded. All AEs were coded by preferred term and system organ class using the latest version of the Medical Dictionary for Regulatory Activities. All patients were followed up for safety assessment at visit 1 (day 1 to day 6), visit 2 (day 12), visit 3 (day $30 \pm 5$ days), visit 4 (day $60 \pm 5$ days) and visit 5 (day $90 \pm 5$ days).

\subsection{Assessment of Neurological Outcome}

The efficacy of sovateltide was evaluated using three different outcome measures. The proportion of patients with change in NIHSS, mRS and BI scores was evaluated on day 6 , day 30 and day 90 post-randomization. Improvements of $\geq 6$ points in NIHSS, $\geq 2$ points in the $\mathrm{mRS}$ or $\geq 40$ points in BI scale from baseline were considered a favorable outcome. Comprehensive analysis of complete recovery was undertaken at 3 months post-randomization using three different outcome scales in patients from the saline and sovateltide groups. Complete recovery was defined as a patient having an NIHSS score of 0 , an mRS score of 0 and a BI score of 100. Quality of life was assessed using two different scales: the EQ-5D and the SSQoL. In the EQ-5D, a score of 100 was defined as the best possible health. Similarly, in the SSQoL, a score of $>200$ was defined as the best health. Both these measurements were done on day 60 and day 90 post-randomization.

\subsection{Blinding/Unblinding}

In this double-blind study, the patients and all relevant personnel involved with the conduct and interpretation of the study (including the investigator, investigational site personnel, and the sponsor or designee's staff) were blinded to the identity of the assigned study drug (sovateltide/normal saline) and the randomization codes. Healthcare professionals were certified in administration of the NIHSS and other scales and were unaware of the assessment status recorded on the previous visit. The biostatistician/unblinded pharmacist was independent of the study team. Dispensing activity was monitored by an unblinded monitor independent of the monitoring team. The final randomization list was kept strictly confidential and accessible only by authorized people per sponsor until the completion of the study. Emergency unblinding through IWRS was available.

\subsection{Sample Size and Statistical Methods}

Data obtained from earlier clinical studies of stroke in the literature were considered to determine the sample size for this phase II study. Assuming $80 \%$ power and a 5\% significance level, a sample size of 32 patients (16 patients in each group) was required. Assuming a 10\% loss to follow-up, a final sample size of 36 patients was required. To increase the power of the study, we increased the sample size to 40 patients (20 patients in each group).

The results of the trial are presented as mean \pm standard error of the mean (SEM). The unpaired t-test with Welch's correction was used to analyze two sets of data with equal variances, and a two-sided p-value was used to determine the level of significance. The unpaired t-test was used to compare discrete variables between the two sets of data at baseline and at follow-ups. Non-parametric analysis was carried out using one-way analysis of variance without assuming equal variances. This test was used for multiple comparisons, and the significance of differences was estimated using Tukey's multiple comparisons test. The Chi-squared test was used to compare the groups, and the two-sided p-value was used for significance. $p<0.05$ was considered significant at a 95\% confidence level, and $p=0.10$ was considered significant at a 90\% confidence level. The Baptista-Pike method was used to calculate odds ratios (ORs). Demographic variables and patient characteristics were summarized descriptively by treatment assignments. Demographic variables include age, weight, height, and body mass index (BMI). Continuous variables, such as patient age at enrollment, number of non-missing observations $(n)$, mean and SEM were tabulated by treatment assignment. All available data were used in the analyses. Each group was summarized individually. Unavailable data were assessed as "missing values," and only the observed population was evaluated. The statistical analysis was processed with GraphPad Prism 8.1.1 (GraphPad, San Diego, CA, USA).

\section{Results}

\subsection{Demographics and Patient Characteristics}

A total of 516 patients were assessed in seven clinical sites across India, of which 40 patients met the eligibility criteria (Table 1). To be eligible for this study, patients had to 
be diagnosed with stroke for the first time. The majority of patients screened for this study had experienced a recurrent stroke so were considered screen failures and not enrolled in the study. All 40 eligible patients signed informed consent and were randomized to either placebo saline $(n=20)$ or sovateltide $(n=20)$. Of these 40 patients, 36 completed the study with 90-day follow-up. In each group, 18 patients completed the study (one patient in each group withdrew consent, and one patient in each group was withdrawn by the investigator) (Fig. 1). Patient demographics and baseline characteristics were comparable between the two groups, including baseline NIHSS (saline $9.17 \pm 0.89$; sovateltide $9.72 \pm 0.94$ ), mRS (saline $3.72 \pm 0.11$; sovateltide $3.78 \pm$ 0.10 ) and BI (saline $35.56 \pm 5.60$; sovateltide $32.22 \pm 4.75$ ) scores (Table 2). Both groups included more male than female patients, and the proportion of males was higher in the sovateltide group ( 15 males and 3 females for sovateltide vs. 11 males and 7 females for saline). Age, body weight and BMI were similar in each group. Table 3 shows the case details of individual patients in each cohort, their medical history, stroke details (radiological findings), state of other cardiovascular diseases and NIHSS and mRS scores at admission.

SOC in both groups was similar; treatment details are given in Table 4. All patients received the study drug or saline within $24 \mathrm{~h}$ of onset of stroke. However, more patients received treatment within $20 \mathrm{~h}$ of stroke onset in the saline group than in the sovateltide group (Fig. 2).

\subsection{Safety/Tolerability}

Every enrolled patient in the sovateltide group received all nine doses; no patients experienced any safety issues after receiving the drug. All patients who received treatment were included in the safety analysis. Compliance with the protocol was excellent in this trial. Sovateltide treatment had no effect on hemodynamic, biochemical or hematological parameters. No drug-related adverse events were reported. No mortality or incidence of recurrent ischemic stroke occurred in any enrolled patients. Sovateltide was safe and well-tolerated in patients with ischemic stroke.

\subsection{Recovery with Sovateltide}

Figure 3 presents the clinical markers of neurological outcome in individual patients from day 1 through day 90 , using three different scales. Figure 3 a presents the NIHSS scores of individual patients on day 1 (baseline) and days 2 , $3,6,12,30$ and 90 post randomization for both saline and sovateltide groups. Data indicate a trend of early recovery in patients receiving sovateltide compared with saline. A significant improvement in NIHSS score was observed compared with day 1 in the sovateltide group (sovateltide - day 3 NIHSS vs. baseline, $p<0.0001$; saline - day 3 NIHSS vs. baseline, $p=0.5771)$. Figure $3 \mathrm{~b}$ presents the mRS scores of individual patients on day 1 (baseline) and day 6, 30, 60 and 90 post randomization for both saline and sovateltide groups. A significant improvement in mRS score indicates a trend of early recovery for patients receiving sovateltide (sovateltide - day $6 \mathrm{mRS}$ vs. baseline, $p<0.0001$; saline - day $6 \mathrm{mRS}$ vs. baseline, $p=0.0859$ ). Figure $3 \mathrm{c}$ shows the BI score of individual patients on day 1 (baseline) and days 6, 30 and 90 post randomization for both saline and sovateltide groups. A significant improvement in BI scores indicates a trend of early recovery for patients receiving sovateltide compared with saline (sovateltide - day $6 \mathrm{BI}$ vs. baseline, $p<0.0001$; saline - day 6 BI vs. baseline, $p=0.3948$ ). Clinical markers of neurological outcome on day 1 versus day 6 in NIHSS scores are presented in Fig. 4 . An improvement of $\geq 6$ points in NIHSS from baseline was seen in $87.50 \%$ of patients treated with sovateltide compared with $12.50 \%$ of those receiving saline ( $p=0.0201)$. These data further support the conclusion that patients treated with sovateltide recovered much quicker than patients treated with saline.

Table 1 Sites participating in the study

\begin{tabular}{llc}
\hline Site no. & Study site & Total enrolled \\
\hline 1 & NewEra Hospital, Near Jalaram Mandir, Queta Colony, Telephone Exchange Chowk, Central Avenue Road, Nagpur & 12 \\
& 440008 Maharashtra & \\
2 & Christian Medical College and Hospital, Department of Neurology, Brown Road, Ludhiana -141008 Punjab & 02 \\
3 & All India Institute of Medical Sciences, Department of Neurology, Neurosciences Centre, Ansari Nagar, New Delhi - & 08 \\
& 110029 & \\
4 & Sanjay Gandhi Post Graduate Institute of Medical Sciences, Department of Neurology, Ground Floor, Raebareli Road, & 05 \\
5 & Lucknow - 226014 Uttar Pradesh & 01 \\
6 & Paras Hospital, C-1, Sushant Lok-1, Sector-43, Gurgaon 122002, Haryana & 10 \\
7 & Dayanand Medical College and Hospital, Tagore Nagar, Civil Lines, Ludhiana, 141001 Punjab & 02 \\
\hline
\end{tabular}




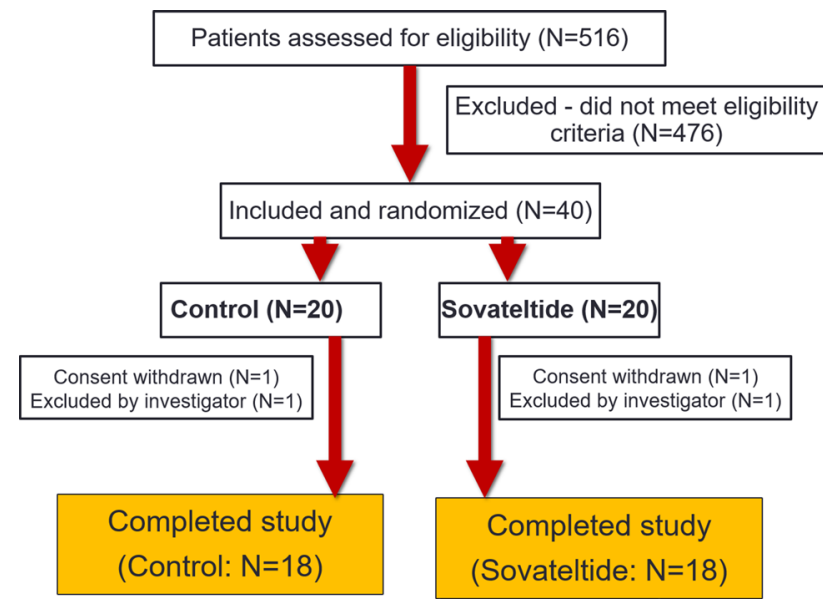

Fig. 1 Screening and enrollment of patients

\subsection{Frequency of Favorable Outcomes at Day 90}

Sovateltide increased the frequency of favorable outcomes at day 90. An improvement of $\geq 2$ points in $\mathrm{mRS}$ score was observed in 60 and $40 \%$ of patients in the sovateltide and saline groups, respectively ( $p=0.0519$; OR 5.25); this did not reach significance at the $95 \%$ confidence level but was significant at the $90 \%$ confidence level. BI improvement of $\geq$ 40 points was seen in 64 and $36 \%$ of those in the sovateltide and saline groups, respectively ( $p=0.0112$; OR 12.44). An improvement of $\geq 6$ points in NIHSS score was seen in 56 and $43 \%$ of patients in the sovateltide and saline groups, respectively ( $p=0.2714$; OR 2.275) (Fig. 5). Although statistical significance was not reached in NIHSS scores, the trend clearly shows an improvement in favorable outcomes.

\subsection{Frequency of Complete Recovery}

Data analysis shows that the sovateltide group had more patients with an NIHSS score of $0(p=0.04791)$ and more patients with a BI score of 100 , indicating that sovateltide increased the frequency of complete recovery compared with saline $(p=0.02795)$. The sovateltide group also had more patients with an mRS score of $0(p=0.1193)$, but this was not statistically significant. There is a clear trend towards complete recovery with sovateltide compared with saline, although it did not reach the level of statistical significance in all clinical scales; however, the OR was $\geq 2.0$. In the sovateltide group, $66 \%$ of patients had an NIHSS score of $0-1$ compared with 50\% in the saline group (OR 2.00; 95\% confidence interval $[\mathrm{CI}] 0.506-6.965 ; p=0.3105)$. In the sovateltide group, $72 \%$ of patients had an mRS score of $0-1$ compared with 55\% in the saline group (OR 2.08; $95 \%$ CI $0.484-8.476 ; p=0.2979)$. Similarly, in the sovateltide group, $66 \%$ of patients had a BI score of 95-100 compared with $33 \%$ in the saline group (OR 4.00; 95\% CI 1.00-16.05; $p=0.0455)$. These results show a trend towards complete recovery in the sovateltide group compared with the saline group, although it did not reach statistical significance in all the clinical outcome scales (Fig. 6).

\subsection{Quality of Life}

Statistical analysis of EQ-5D data on day 60 showed an OR of 3.250 (95\% CI 0.7181-11.52); the outcome in the sovateltide group was $225 \%$ likely to be better than that in the saline group. EQ-5D data on day 90 showed that the outcome in the sovateltide group was $95 \%$ likely to be better than that in the saline group (Fig. 7). Statistical analysis of SSQoL data on day 60 showed an OR of 1.429 (95\% CI 0.3565-4.907); the outcome in the sovateltide group was $42 \%$ likely to be better than that in the saline group. SSQoL data on day 90 showed an OR of 3.429 (95\% CI 0.7909-15.47), indicating that the outcome in the sovateltide group was $242 \%$ likely to be better than that in the saline group (Fig. 7).

\section{Discussion}

Rapid restoration of blood flow by removing or dissolving thrombus from blood vessels is considered the primary intervention of choice for ischemic stroke. tPA and mechanical thrombectomy [31] are the currently available treatments but are beneficial only if provided quickly after the onset of stroke. Administration of tPA after $4.5 \mathrm{~h}$ of onset of stroke has shown no benefit [32] and involves the risk of hemorrhagic transformation, leading to highly significant morbidity and mortality [32]. Stroke pathophysiology involves hypoxia, vascular damage, inflammation, apoptosis

Table 2 Demographics of patients in standard-of-care plus saline and standard-of-care plus sovateltide cohorts

\begin{tabular}{llllrr}
\hline Group & Sex & Age (years) & Body weight $(\mathrm{kg})$ & Height $(\mathrm{cm})$ & BMI $\left(\mathrm{kg} / \mathrm{m}^{2}\right)$ \\
\hline Normal saline $(N=18)$ & $11 \mathrm{M} / 7 \mathrm{~F}$ & $58.34 \pm 1.73$ & $64.97 \pm 2.40$ & $163.72 \pm 2.08$ & $24.47 \pm 0.98$ \\
Sovateltide $(N=18)$ & $15 \mathrm{M} / 3 \mathrm{~F}$ & $49.83 \pm 2.79$ & $67.82 \pm 2.47$ & $168.78 \pm 1.50$ & $24.00 \pm 0.68$ \\
\hline
\end{tabular}

Data are presented as mean \pm standard error of the mean

$B M I$ body mass index, $F$ female, $M$ male 


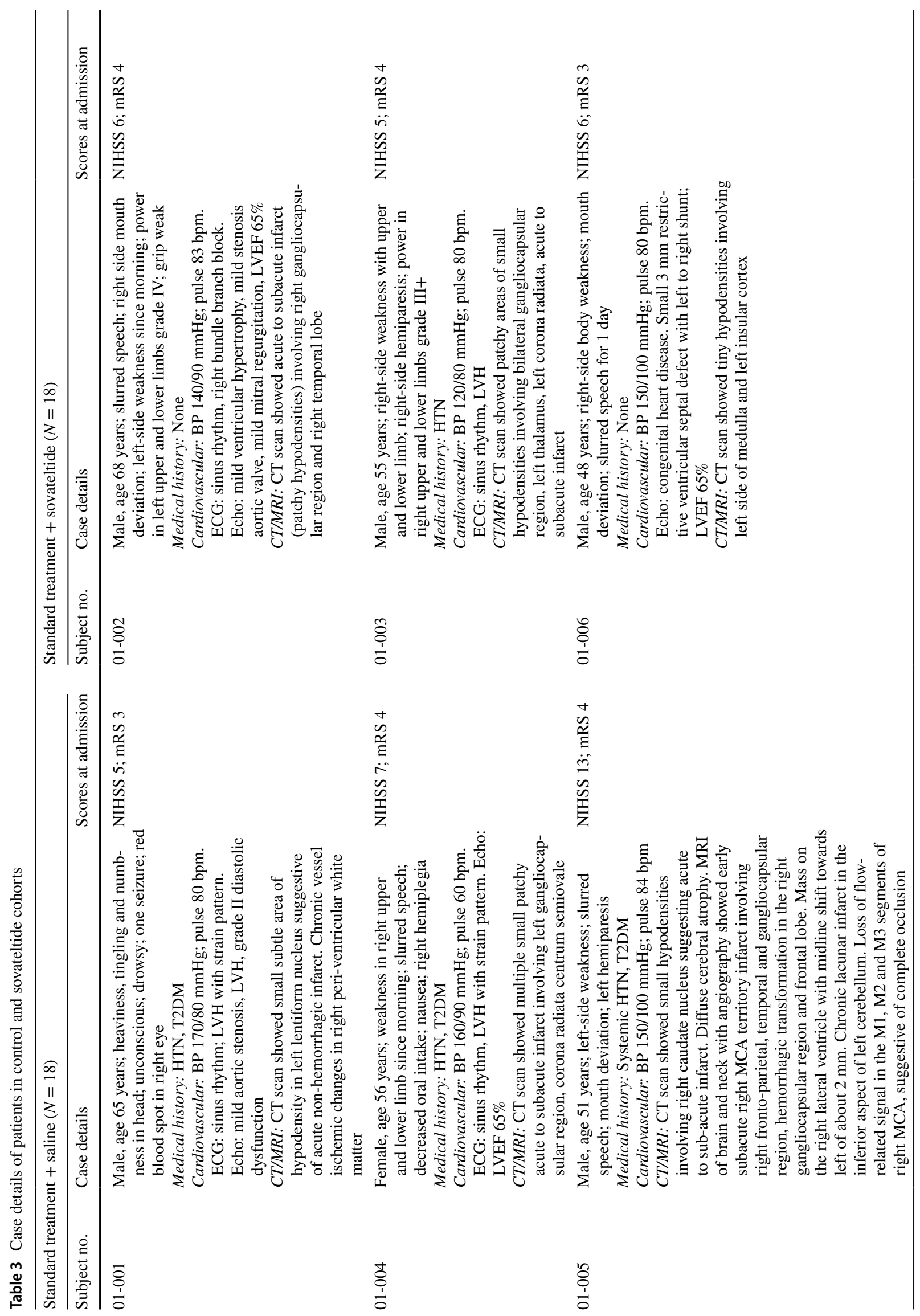




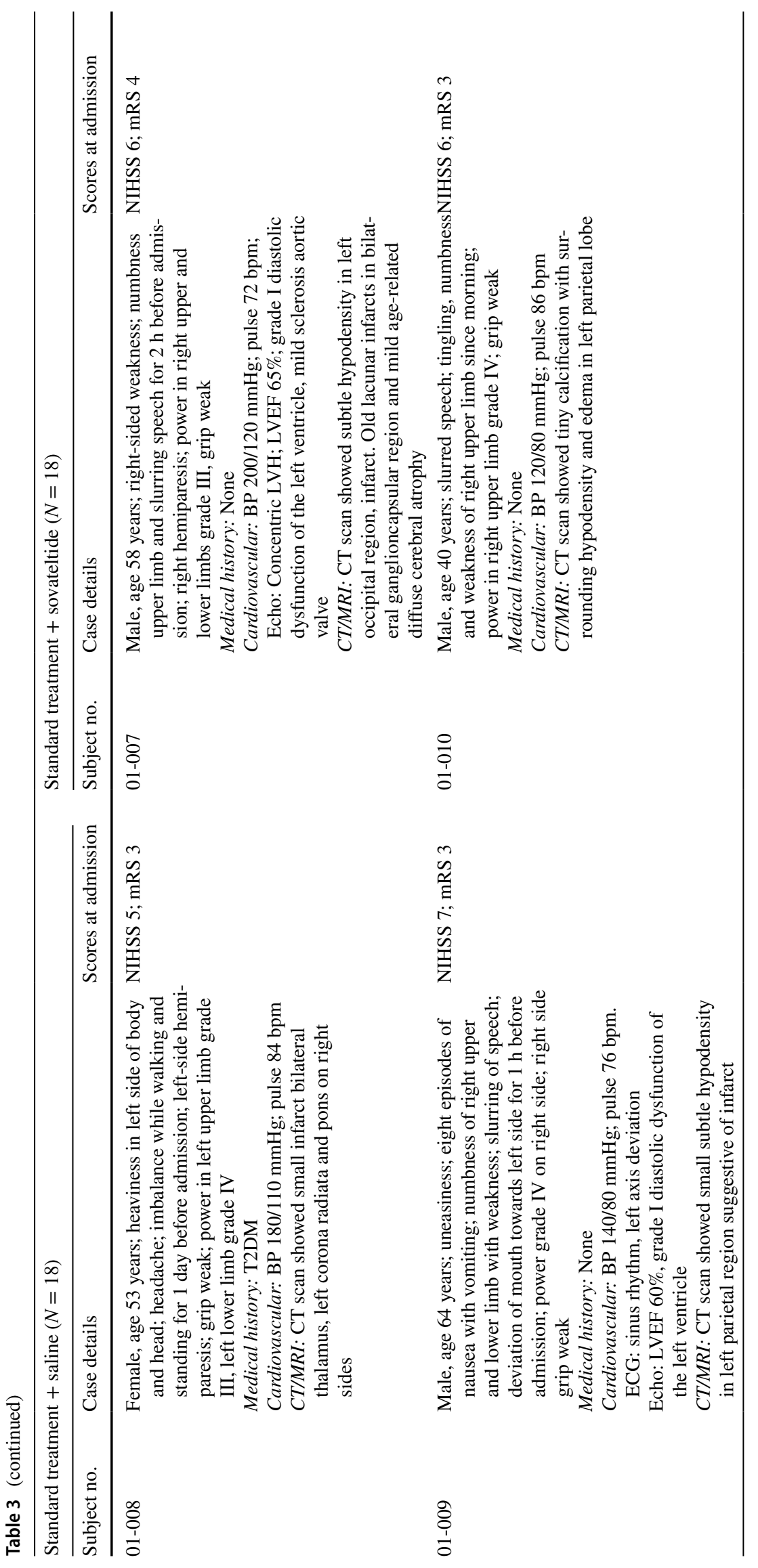




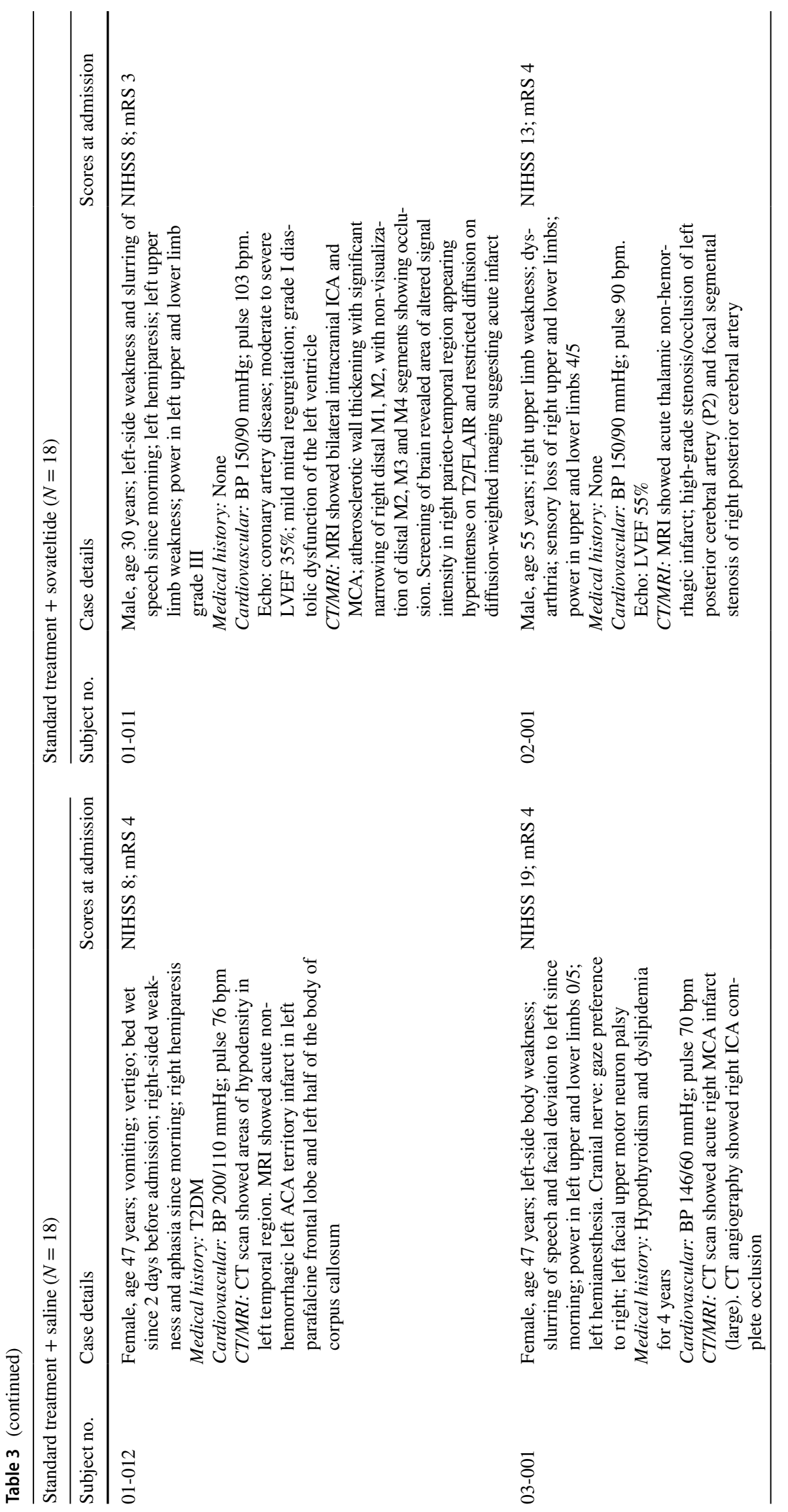




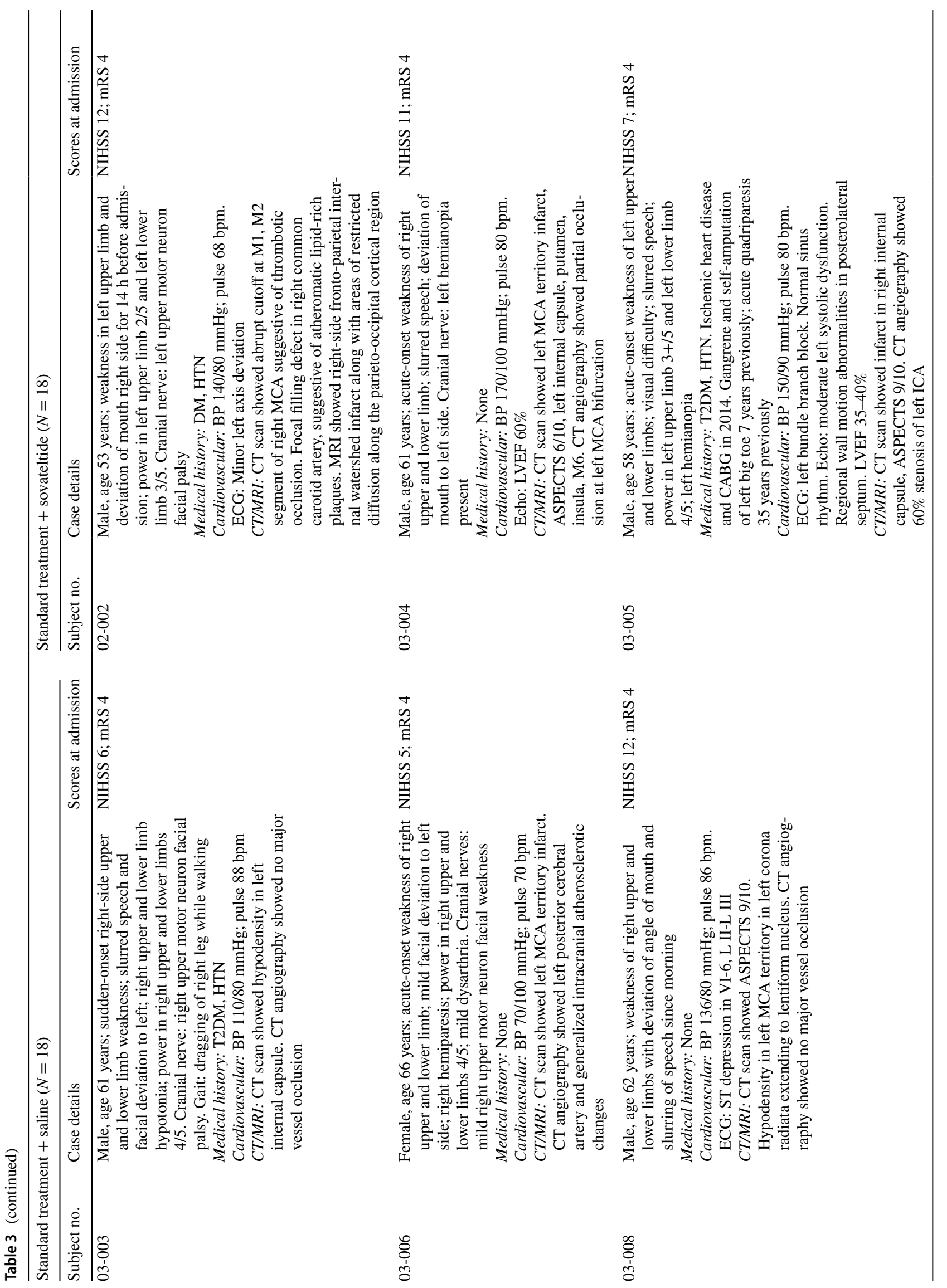




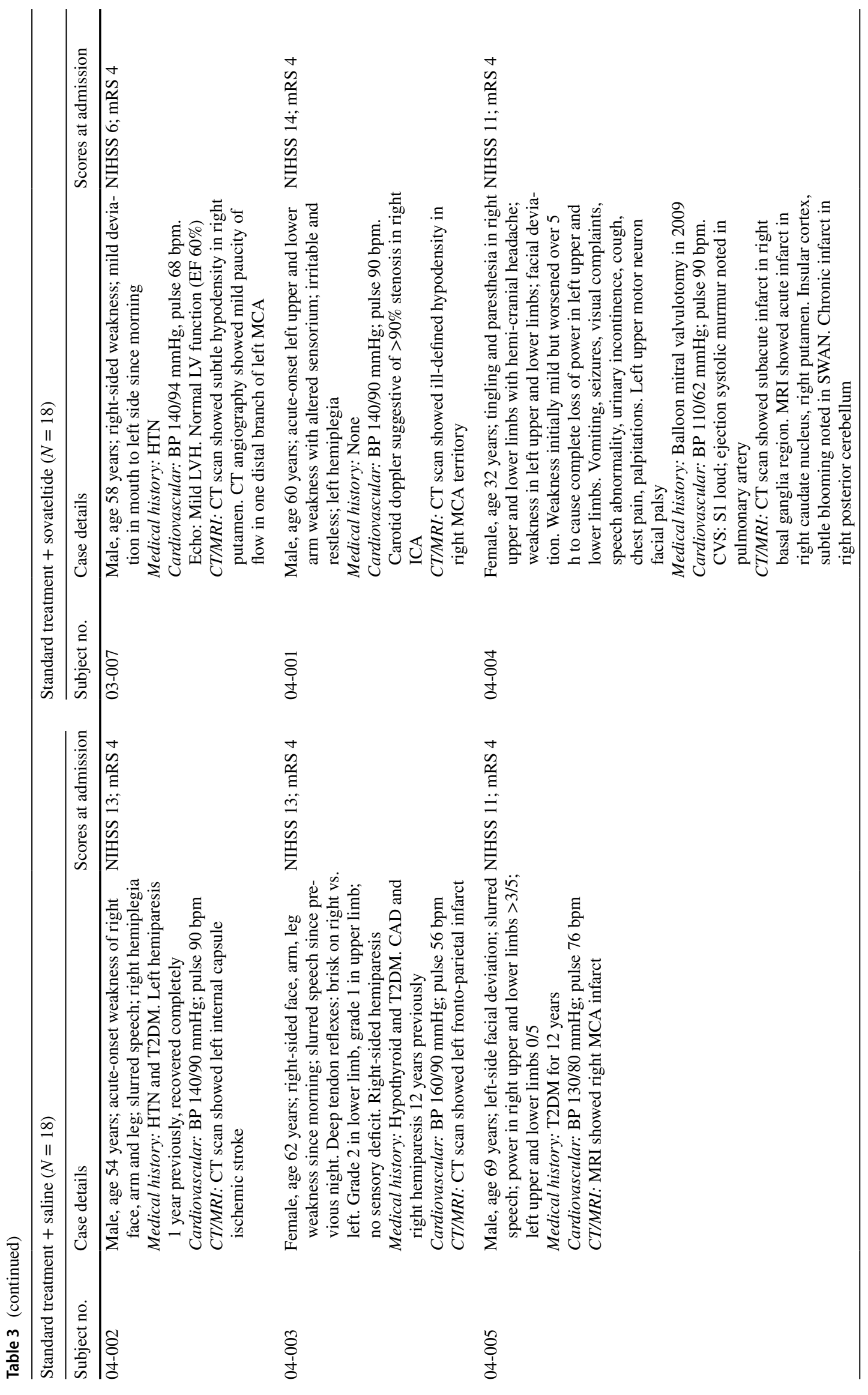




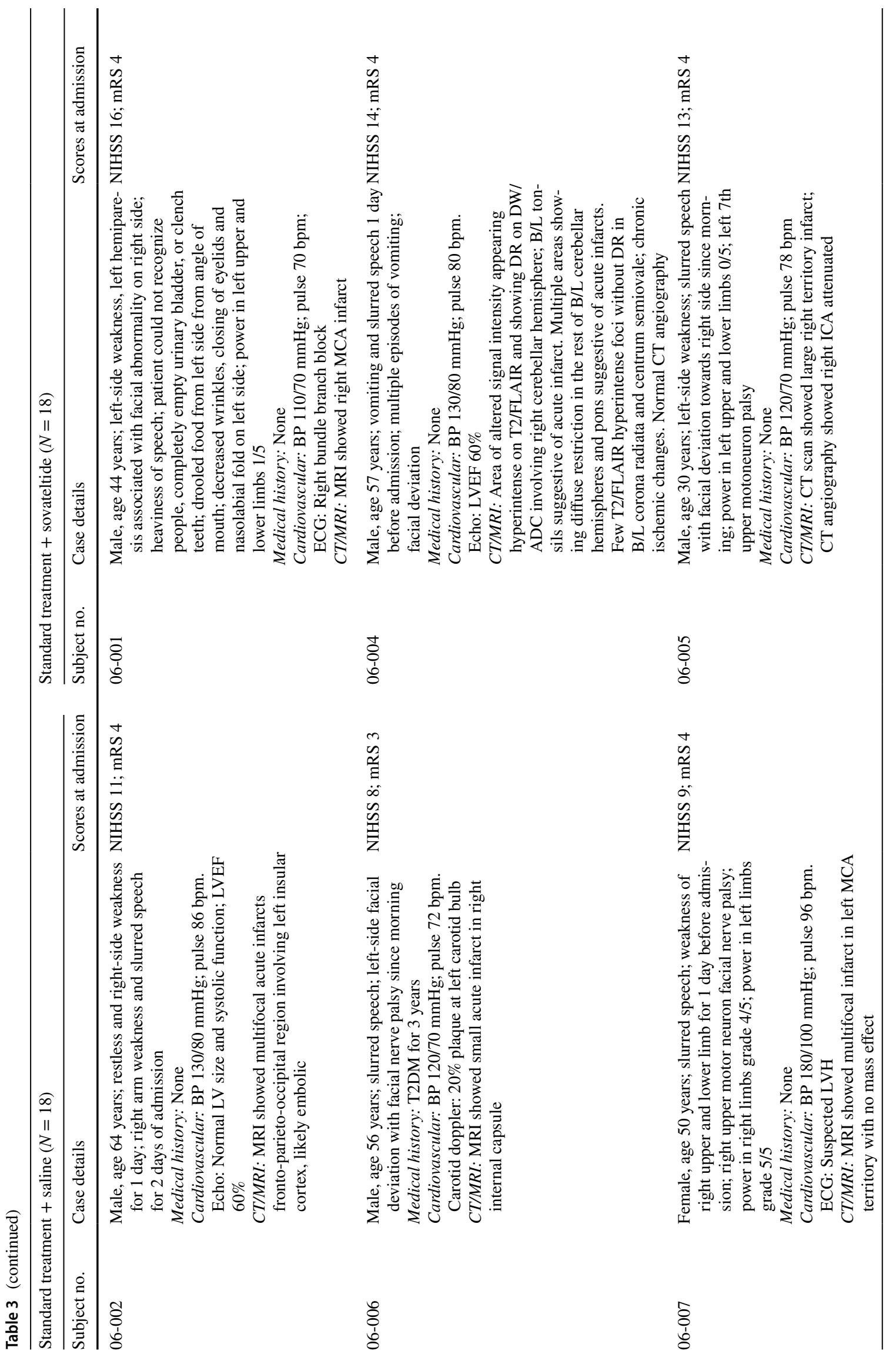




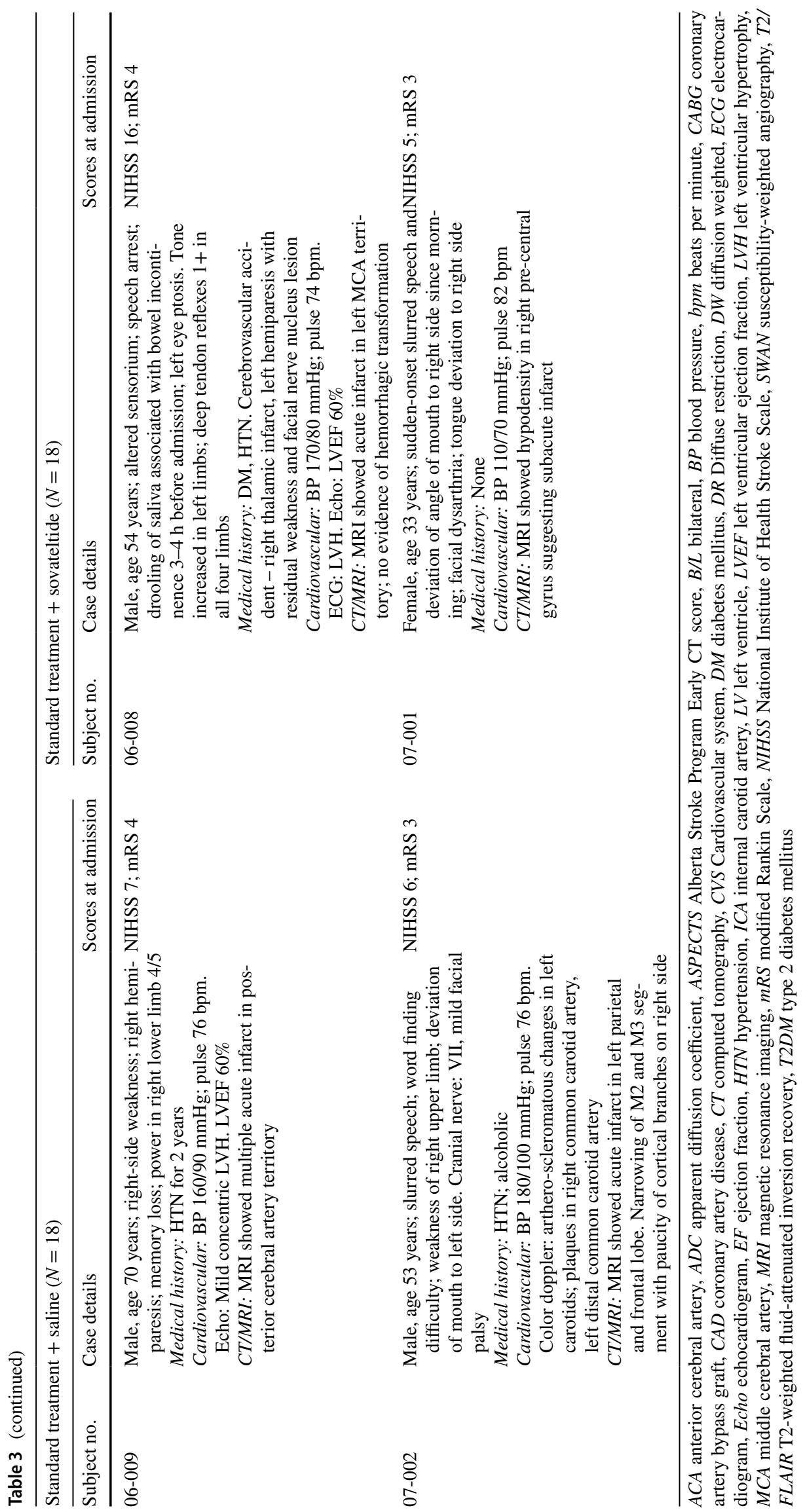


andwother events that severely affect neuronal cells [33]. Neuronal and glial cells are major components of neural tissues in the CNS, and both are generated from common Nestin-expressing neural stem/progenitor cells [34, 35]. Survival and directed differentiation of progenitor cells has been shown to play an important role in regeneration of damaged tissues in different organs, including the brain [36]. Vascular endothelial growth factor enhances both angiogenesis and neurogenesis [37]. In a rat model of cerebral ischemia, human trophoblast progenitor cells enhanced expression of angiogenic and neurogenic factors in the brain and significantly decreased infarct volume [38]. A non-randomized open-label phase I study of autologous cluster of differentiation (CD)-34+ selected stem/progenitor cell therapy in patients with cerebral ischemic stroke with NIHSS scores $\geq 8$ and within 7 days of stroke onset showed improvement in mRS and NIHSS scores during 6-month follow-up [39]. Patients with chronic stroke, functional deficits and NIHSS scores $\geq 6$ transfused intravenously with mesenchymal stem cells over the 12 months of follow-up reported increases in BI scores $(p<0.001)$ of $10.8 \pm 15.5$ points [40]. It appears that using stem cells or progenitor cells may have promise in improving the outcomes of patients with acute cerebral ischemic stroke.

Intravenous sovateltide resulted in higher neuronal progenitor cell (NPC) differentiation and better mitochondrial morphology and biogenesis in the brain of stroked rats [41, 42]. Exposure of cultured NPCs to hypoxia also showed

Table 4 Standard-of-care details of the treatment in control and sovateltide group of patients

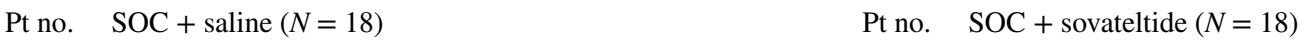

01-001 Enoxaparin injection, aspirin tablet, rosuvastatin tablet, cilnidipine and chlorthalidone tablet

01-004 Enoxaparin injection, aspirin tablet, clopidogrel and rosuvastatin tablet

01-005 Cognistar injection, levetiracetam tablet, mannitol injection, rosuvastatin tablet, amlodipine tablet, aspirin tablet, furosemide tablet, rosuvastatin tablet

01-008 Enoxaparin injection, aspirin and clopidogrel tablet, rosuvastatin tablet

01-009 Aspirin and clopidogrel tablet, atorvastatin tablet, cognistar injection

01-012 Enoxaparin injection, cognistar injection, aspirin and clopidogrel tablet, rosuvastatin tablet, amlodipine tablet

03-001 Mannitol, aspirin tablet, amlodipine tablet, atorvastatin tablet

03-003 Aspirin tablet, atorvastatin tablet

03-006 Amlodipine tablet, aspirin tablet, clopidogrel tablet, atorvastatin tablet

03-008 Amlodipine tablet, tenecteplase, aspirin tablet, atorvastatin tablet

04-002 Aspirin and atorvastatin capsule

04-003 Aspirin and atorvastatin capsule, clopidogrel tablet

04-005 Atorvastatin tablet, aspirin tablet, telmisartan tablet, clopidogrel tablet

06-002 Aspirin and clopidogrel tablet, mannitol injection, atorvastatin tablet, dalteparin injection

06-006 Aspirin tablet, atorvastatin tablet, telmisartan and amlodipine tablet

06-007 Aspirin tablet, atorvastatin tablet, amlodipine tablet, telmisartan tablet, fluoxetine capsule

06-009 Telmisartan and amlodipine tablet, aspirin, atorvastatin and clopidogrel tablet, memantine tablet

07-002 Aspirin tablet, atorvastatin tablet
01-002 Enoxaparin injection, rosuvastatin tablet, amlodipine tablet, aspirin and clopidogrel tablet

01-003 Amlodipine tablet, enoxaparin injection, cognistar injection, aspirin tablet, clopidogrel, telmisartan tablet, rosuvastatin tablet

01-006 Enoxaparin injection, aspirin and clopidogrel tablet, amlodipine tablet

01-007 Enoxaparin injection, aspirin and clopidogrel tablet, rosuvastatin tablet, cognistar injection, labetalol tablet, amlodipine tablet, nifedipine tablet

01-010 Enoxaparin injection, aspirin and clopidogrel tablet, mannitol injection

01-011 Atorvastatin tablet, enoxaparin injection, cognistar injection, nicoumalone tablet

02-001 Alteplase injection, aspirin tablet, atorvastatin tablet, escitalopram tablet, telmisartan tablet

02-002 Heparin injection, aspirin tablet, atorvastatin tablet, enoxaparin injection

03-004 Amlodipine tablet, alteplase, aspirin tablet, atorvastatin tablet

03-005 Metoprolol tablet, aspirin tablet, clopidogrel tablet, ramipril tablet, atorvastatin tablet

03-007 Atorvastatin tablet, aspirin tablet, clopidogrel tablet, fluoxetine tablet, amlodipine tablet

04-001 Aspirin and atorvastatin capsule

04-004 Nicoumalone tablet, furosemide and spironolactone tablet, enoxaparin injection

06-001 Aspirin tablet, clopidogrel tablet, atorvastatin tablet, trimetazidine tablet

06-004 Aspirin tablet, atorvastatin tablet

06-005 Aspirin tablet, mannitol injection, enoxaparin injection, furosemide injection, atorvastatin tablet

06-008 Olmesartan and amlodipine tablet, atorvastatin tablet, phenytoin syrup, aspirin and clopidogrel tablet

07-001 Aspirin tablet, atorvastatin tablet

$p t$ patient, SOC standard of care 


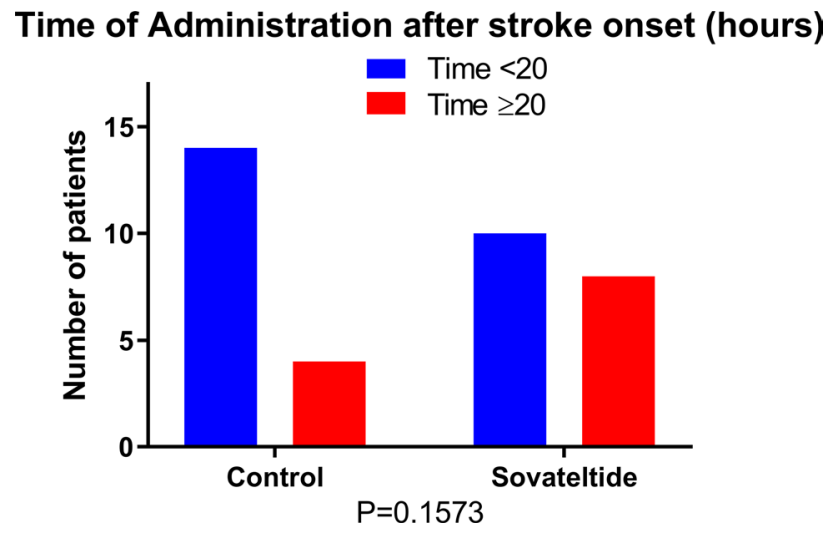

Fig. 2 Time of initiating the treatment after onset of stroke

higher NPC differentiation and maturation with sovateltide $[41,42] . \mathrm{ET}_{\mathrm{B}}$ receptors are vital for the development of neural crest-derived epidermal melanocytes and enteric neurons $[19,27,28,43,44] . \mathrm{ET}_{\mathrm{B}}$ receptors are known to regulate the differentiation, proliferation and migration of neurons, melanocytes and glia of both the enteric system and the CNS during pre- and post-natal development [5, 20, $23,45] . \mathrm{ET}_{\mathrm{B}}$ receptor knock-out in rodents led to mortality within 4 weeks of birth [46, 47], craniofacial malformation [48, 49], increased apoptosis, and a significantly lower number of NPCs in the CNS. It has been demonstrated that $\mathrm{ET}_{\mathrm{B}}$ receptors in the brain are overexpressed at the time of birth and that their expression decreases with maturity of the brain $[21,50]$. We have successfully used sovateltide as a novel pharmacological tool to activate a regenerative response in the ischemic brain by stimulating $\mathrm{ET}_{\mathrm{B}}$ receptors $[24,25,29,30]$.

Stimulation of $\mathrm{ET}_{\mathrm{B}}$ receptors by sovateltide facilitated restoration of cerebral blood flow and improvement in neurological and motor function in a rat model of cerebral ischemia [24, 25, 29, 30]. Sovateltide-treated animals showed strong evidence of neural tissue repair and regeneration, including decreased infarct volume and oxidative stress, increased pro-angiogenic, pro-survival and antiapoptotic markers; and increased numbers of proliferating cells [24, 25, 29, 30, 41, 42]. The SONAR trial administered a selective $\mathrm{ET}_{\mathrm{A}}$ receptor antagonist (leaving $\mathrm{ET}_{\mathrm{B}}$ receptors unblocked) in patients with type 2 diabetes mellitus with chronic kidney disease [51], who have a significantly greater risk of cardiovascular accidents [52], providing indirect supporting evidence of a reduced number of nonfatal strokes in these patients. Unblocked $\mathrm{ET}_{\mathrm{B}}$ receptors can be stimulated by endogenous circulating ET-1 to produce a neuroprotective effect, because $\mathrm{ET}_{\mathrm{A}}$-selective antagonism produces an overstimulation of $\mathrm{ET}_{\mathrm{B}}$ receptors [53], and ET-3 (more selective for $\mathrm{ET}_{\mathrm{B}}$ receptors) dilates cerebral blood vessels, which was enhanced by $\mathrm{ET}_{\mathrm{A}}$ receptor antagonist $\mathrm{BQ} 123$ [54]. These findings support our argument that sovateltide mediates brain regeneration and repair after ischemic stroke in the adult brain. Further confirmation is provided by
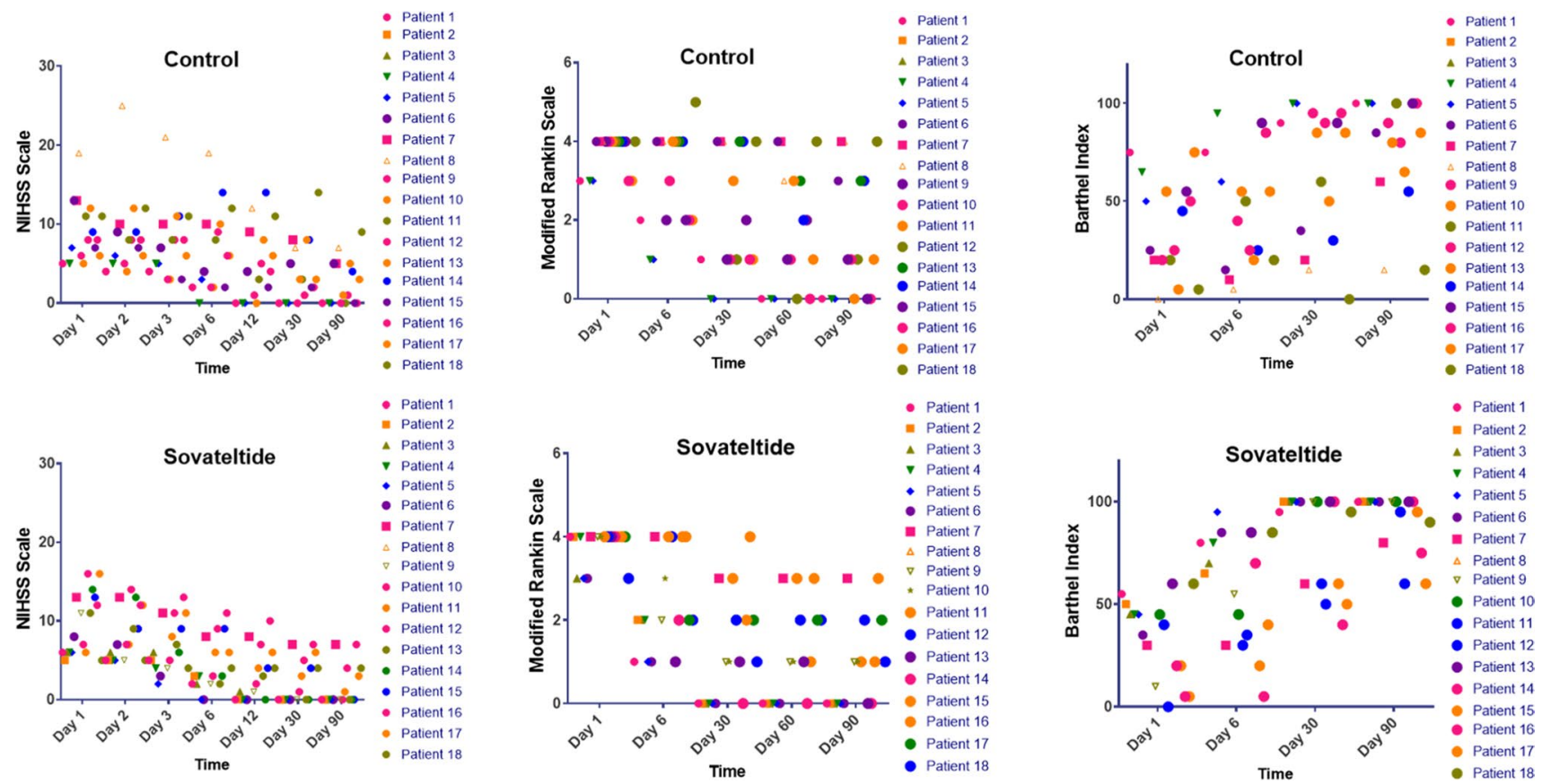

Fig. 3 Neurological outcome measures of National Institute of Health Stroke Scale (NIHSS), modified Rankin Scale (mRS) and Barthel Index (BI) in individual patients from day 1 through day 90 


\section{Change in NIHSS (Day 6)}

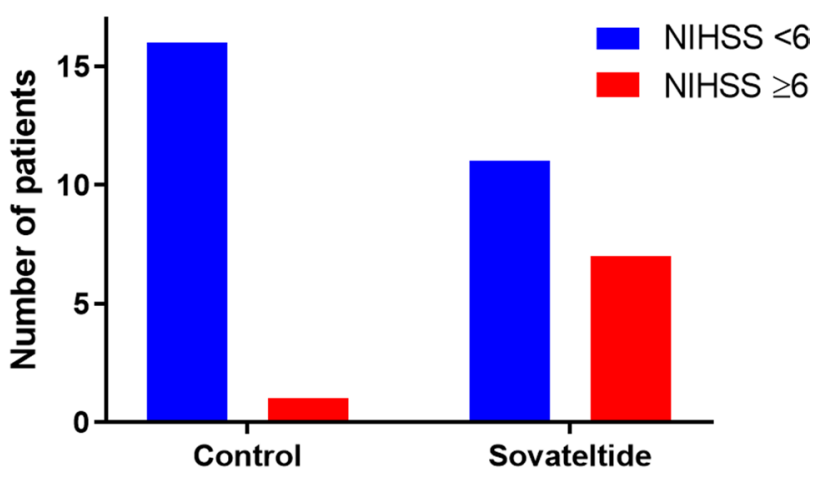

\begin{tabular}{|l|r|r|}
\hline Statistical significance & & \\
\hline Test & Chi-square & \\
\hline P value & 0.0201 & \\
\hline Odds ratio & 10.18 & $95 \%$ CI 1.285 to 120.5 \\
\hline
\end{tabular}

Fig. 4 Neurological outcome measures on day 6 vs day 1 of National Institute of Health Stroke Scale (NIHSS) scores

evidence that selective blockade of $\mathrm{ET}_{\mathrm{B}}$ receptors exacerbates ischemic brain damage [19].

The clinical phase I trial (CTRI/2016/11/007509) in healthy human volunteers determined a safe and maximum tolerated dose of sovateltide [5]. In the present study, we report the results of an exploratory phase II (NCT04046484, CTRI/2017/11/010654) study in patients with ischemic stroke. For the present study, we used three doses of sovateltide $0.3 \mu \mathrm{g} / \mathrm{kg}$ administered as an intravenous bolus over $1 \mathrm{~min}$ at an interval of $3 \pm 1 \mathrm{~h}$ on days 1,3 and 6 (total dose of $0.9 \mu \mathrm{g} / \mathrm{kg} / \mathrm{day}$ ). The half-life of intravenous sovateltide ranged from 4.38 to $8.29 \mathrm{~min}$ at doses of 0.11 $\mu \mathrm{g} / \mathrm{kg}$ and $0.29 \mu \mathrm{g} / \mathrm{kg}$, respectively [55, 56]. The observed half-life of sovateltide was short; however, a longer duration of action is possible because it has been suggested that ET-1 and its receptors form complexes that are internalized and continue to signal [57]. Internalization of ET-1 and its receptor complex into caveolin-containing vesicles occurs within 10 min of ET-1 application, but it continues to signal and provide effects that may last for days [58, 59].

The primary objective of the study was to evaluate the safety and tolerability of sovateltide. Key secondary objectives included efficacy measurements of neurological improvements using the NIHSS, mRS and BI scales and quality-of-life assessments using the EQ-5D and the SSQoL. Sovateltide was well-tolerated, and every patient in the sovateltide group received all nine doses during treatment without any adverse events. Sovateltide treatment was initiated between 8 and $24 \mathrm{~h}$ after the onset of stroke. Sovateltide treatment resulted in a quicker recovery as measured by improvements in mRS and BI scales on day 6 compared with day 1 . Moreover, sovateltide increased the frequency of favorable outcomes at day 90 . An improvement of $\geq 6$ points in NIHSS was seen in $56 \%$ of patients with sovateltide versus $43 \%$ with saline. Although this was not statistically significant, the trend clearly shows an improvement in favorable outcomes. An improvement of $\geq 2$ points in the mRS was observed in 60 and $40 \%$ of patients with sovateltide and saline, respectively. Although changes in mRS score were not significant at the $95 \%$ confidence level, it was significant at the $90 \%$ confidence level. Similarly, a BI improvement of $\geq 40$ points was reported in 64 and $36 \%$ of patients with sovateltide and saline, respectively ( $p=0.0112)$. The number of patients with complete recovery achieving an NIHSS score of 0 and a BI score of 100 was significantly higher $(p<0.05)$ with sovateltide than with saline at the $95 \%$ confidence level. The sovateltide group also had more patients with an mRS score of $0(p=0.1193)$, but this was not statistically significant. These results show a trend towards complete recovery with sovateltide compared with saline,
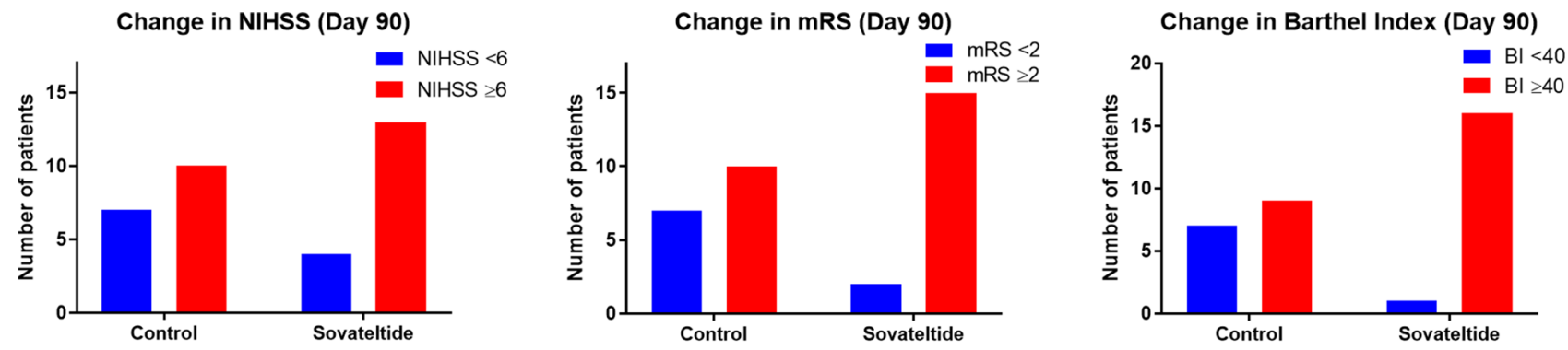

\begin{tabular}{|c|c|c|}
\hline \multicolumn{3}{|c|}{ Change of $>\mathbf{6}$ in NIHSS Day $\mathbf{9 0}(\mathbf{P}=\mathbf{0 . 2 7 1 4})$} \\
\hline Odds ratio & 2.275 & $95 \% \mathrm{Cl} 0.5785$ to 8.310 \\
\hline Percentage & NIHSS $<6$ & NIHSS $\geq \mathbf{6}$ \\
\hline Control & $63.64 \%$ & $43.48 \%$ \\
\hline Sovateltide & $36.36 \%$ & $56.52 \%$ \\
\hline
\end{tabular}

\begin{tabular}{|c|c|c|}
\hline \multicolumn{3}{|c|}{ Change of $>\mathbf{2}$ in $\mathbf{m R S}$ Index Day $\mathbf{9 0}(\mathbf{P}=\mathbf{0 . 0 5 1 9})$} \\
\hline Odds ratio & 5.250 & $95 \% \mathrm{Cl} 1.000$ to 27.63 \\
\hline Percentage & $\mathrm{mRS}<\mathbf{2}$ & $\mathrm{mRS} \geq \mathbf{2}$ \\
\hline Control & $77.78 \%$ & $40.00 \%$ \\
\hline Sovateltide & $22.22 \%$ & $60.00 \%$ \\
\hline
\end{tabular}

\begin{tabular}{|c|c|c|}
\hline \multicolumn{3}{|c|}{ Change of $>\mathbf{4 0}$ in Barthel Index Day $\mathbf{9 0}(\mathbf{P}=\mathbf{0 . 0 1 1 2})$} \\
\hline Odds ratio & 12.44 & $95 \%$ CI 1.502 to 147.1 \\
\hline Percentage & BI $<\mathbf{4 0}$ & BI $\geq \mathbf{4 0}$ \\
\hline Control & $87.50 \%$ & $36.00 \%$ \\
\hline Sovateltide & $12.50 \%$ & $64.00 \%$ \\
\hline
\end{tabular}

Fig. 5 Number of patients with change in National Institute of Health Stroke Scale (NIHSS), modified Rankin Scale (mRS) and Barthel Index (BI) at 90 days of follow up 

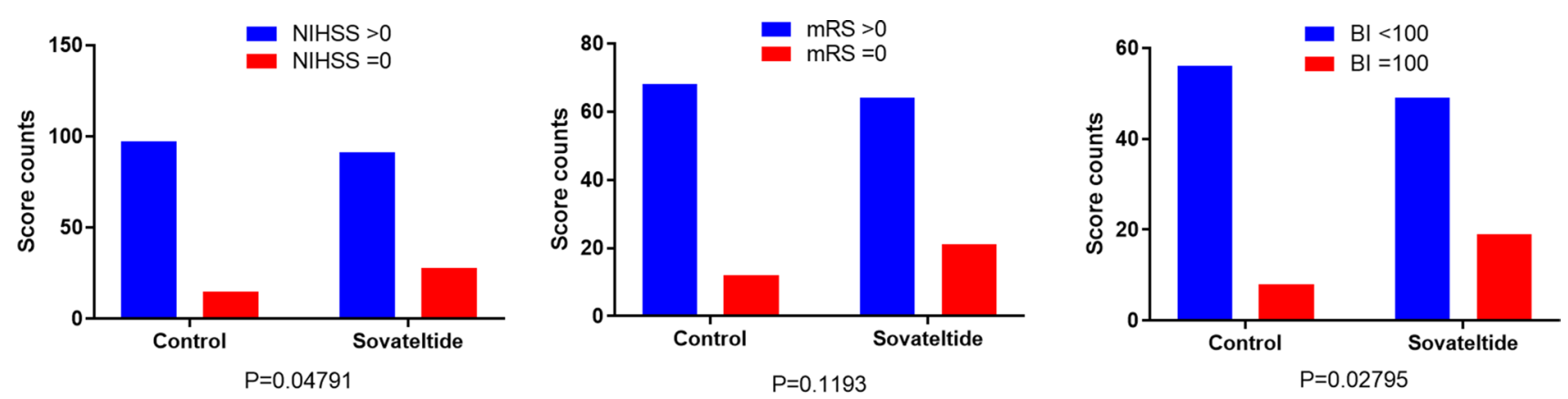

Score (percent) indicating complete neurological recovery

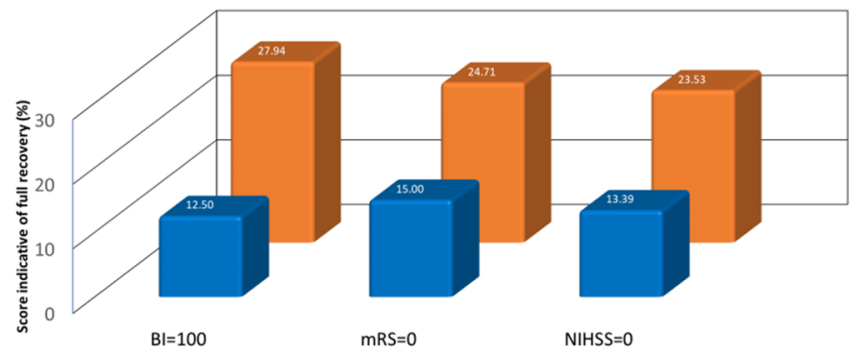

$\square$ Control $\square$ Sovateltide

Fig. 6 Number of patients with complete recovery as indicated by National Institute of Health Stroke Scale (NIHSS), modified Rankin Scale (mRS) and Barthel Index (BI) at 90 days of follow up

although it did not reach statistical significance in all clinical outcome scales. In a landmark recombinant tPA (rtPA) stroke study, complete recovery was defined as an NIHSS score of $0-1$, an mRS score of $0-1$ and a BI score of 95-100 [60]. In this study, complete recovery was experienced by 38 and $50 \%$ of the control and rtPA groups, respectively, according to BI scores; 26 and $39 \%$ of the respective groups according to mRS scores; and 20 and $31 \%$ of the respective groups according to NIHSS scores [60]. The results in our study also showed favorable outcomes, with complete recovery in 12 and $28 \%$ of the saline and sovateltide groups, respectively, according to BI scores; 15 and $24 \%$ of the respective groups according to mRS scores, and 13 and $23 \%$ of the respective groups according to NIHSS scores. Our percentages were lower than those in the rtPA stroke study [60] because we considered an NIHSS score of 0 , a BI score of 100 and an mRS score of 0 to be indicators of complete recovery (Fig. 6). No drug-related adverse events were
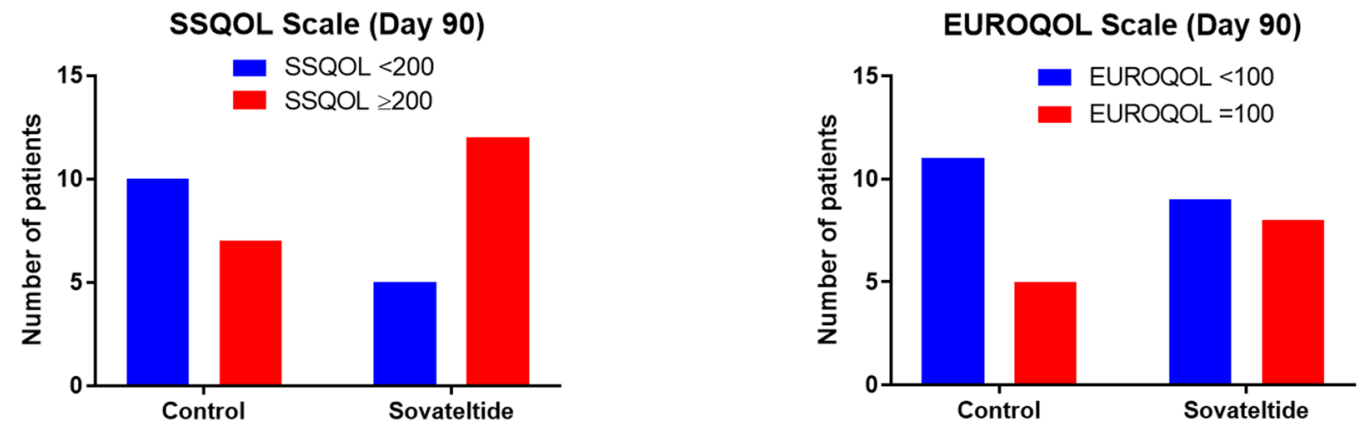

\begin{tabular}{|l|r|l|}
\hline Statistical significance & & \\
\hline Test & Chi-square & \\
\hline P value & 0.0842 & \\
\hline Odds ratio & 3.429 & $95 \%$ CI 0.7909 to 15.47 \\
\hline
\end{tabular}

\begin{tabular}{|l|r|l|}
\hline Statistical significance & & \\
\hline Test & Chi-square & \\
\hline P value & 0.3530 & \\
\hline Odds ratio & 1.956 & $95 \% \mathrm{CI} 0.4213$ to 8.509 \\
\hline
\end{tabular}

Fig. 7 Number of patients with improved quality of life at 90 days of follow up. CI confidence interval, EuroQoL EuroQoL 5-Dimensions tool 
reported. Results indicate a clear superiority of sovateltide over SOC, resulting in better clinical outcomes for patients with acute cerebral ischemic stroke.

Patients enrolled in this study had mild-to-moderate acute ischemic stroke, and patients with lacunar stroke were excluded. The main reason for excluding lacunar stroke was to exclude extreme variability in the assessment of neurological outcome in such strokes. Since this was a study using a potential first-in-class drug product, we took this approach to enable proper comparison with a limited number of patients. All patients $(100 \%)$ had an mRS score $>2$ at enrollment. Further, $83.33 \%$ (15/18) of patients in the saline group and $88.89 \%(16 / 18)$ of those in the sovateltide group had an NIHSS score $\geq 6$ and a BI score $<60$. Stroke in most of the patients was moderate in nature because the NIHSS score was $9.17 \pm 0.89$ and $9.72 \pm 0.94$ in the saline and sovateltide groups, respectively. Similarly, the mRS score was $3.72 \pm 0.11$ and $3.78 \pm 0.10$ in the respective groups, and the BI score was $35.56 \pm 5.60$ and $32.22 \pm 4.75$ in the respective groups. The most important clinical endpoint, recognized by the major regulatory agencies, is $\mathrm{mRS}$ score at 90 days, which was $1.71 \pm 0.41$ and $0.88 \pm 0.26$ in the control and sovateltide groups, respectively; the difference in mean was not statistically significant $(p=0.0965)$ at the $95 \%$ confidence level but was at the $90 \%$ confidence level.

The limitations of this study include that it enrolled a small number of patients and was conducted in one country. The promising results from this study led to an efficacy study in a larger cohort of patients with ischemic stroke, and sovateltide is currently being tested in a multicentric, randomized, blinded, controlled efficacy phase III clinical trial (NCT04047563). The sovateltide group had more younger patients than the control group, which may contribute to better recovery in the former. Another limitation is that more female patients were enrolled in the control group, which could affect the outcome. It has been reported that age-adjusted mortality rates due to stroke are higher for men than women, but women surviving stroke have less favorable outcomes than men [61]. Although our results suggest that sovateltide treatment can be initiated within a window of $24 \mathrm{~h}$ after the onset of stroke, experimental studies in our laboratory indicate that neurological outcomes are better if sovateltide treatment is initiated within $2-6 \mathrm{~h}$ after the onset of stroke [24, 25, 30, 62]. Hence, if sovateltide treatment is initiated quickly after the onset of stroke, a greater improvement in neurological outcome may be possible. In the present study, $22.22 \%$ of patients in the saline group and $44.45 \%$ of those in the sovateltide group received treatment after $20 \mathrm{~h}$ (between 20 and $24 \mathrm{~h}$ ) of onset of stroke. This delay in sovateltide treatment could have negatively affected neurological recovery.

\section{Conclusions}

Sovateltide was safe and well-tolerated in patients with ischemic stroke. This is the first and thus far only study to assess the effect of sovateltide on neurological outcome in patients with acute cerebral ischemic stroke. This was an exploratory phase II study because using sovateltide is a completely new approach in the treatment of stroke. Sovateltide administered intravenously in patients with acute cerebral ischemic stroke showed significant improvement in several but not all parameters of neurological outcome.

Author contributions Conceptualization: AG. Data curation: NA, DV, UKM, BP, DJ, JP and RB. Formal analysis: AG. Funding acquisition: AG. Performed study: NA, DV, UKM, BP, DJ, JP and RB. Methodology: AG, NA, DV, UKM, BP, DJ, JP and RB. Project administration: AG, NA, DV, UKM, BP, DJ, JP and RB. Data creation: NA, DV, UKM, BP, DJ, JP and RB. Writing —original draft: AG. Writing-review and editing: AG, NA, DV, UKM, BP, DJ, JP and RB.

\section{Declarations}

Funding Pharmazz, Inc. Willowbrook, IL, USA, provided funding for this study and paid the open access fee.

Conflict of interest Dr. Anil Gulati (AG) is an employee of Pharmazz, Inc. and has issued and pending patents relating to this study. Nilesh Agrawal, Deepti Vibha, UK Misra, Birinder Paul, Dinesh Jain, Jeyaraj Pandian and Rupam Borgohain have no conflicts of interest that are directly relevant to the content of this article.

Ethics approval The study protocol (PMZ-01 version 2.0/April 18, 2016) was approved by the Drugs Controller General of India, Directorate General of Health Services, Ministry of Health and Family Welfare, Government of India, and the institutional ethics committee of each of the seven sites (who reviewed and approved the study protocol before initiation of patient enrolment at each site). The study was registered at the Clinical Trials Registry, India (CTRI/2017/11/010654) and the US National Library of Medicine, ClinicalTrials.gov (NCT04046484).

Data availability The datasets generated and/or analyzed during the current study are available from the corresponding author on reasonable request.

Consent to participate Informed consent was obtained from each patient or from their LAR if they were not fit to give consent themselves at the time of treatment initiation. The investigator informed the patient/LAR in writing and audio-visual recording about all aspects of the study relevant to taking a decision on whether or not to participate in the study. The informed consent form included all the elements required by ICH-GCP recommendations and schedule Y.

Consent for publication Not applicable.

Code availability Not applicable.

Open Access This article is licensed under a Creative Commons Attribution-NonCommercial 4.0 International License, which permits any non-commercial use, sharing, adaptation, distribution and reproduction in any medium or format, as long as you give appropriate credit to the 
original author(s) and the source, provide a link to the Creative Commons licence, and indicate if changes were made. The images or other third party material in this article are included in the article's Creative Commons licence, unless indicated otherwise in a credit line to the material. If material is not included in the article's Creative Commons licence and your intended use is not permitted by statutory regulation or exceeds the permitted use, you will need to obtain permission directly from the copyright holder. To view a copy of this licence, visit http://creativecommons.org/licenses/by-nc/4.0/.

\section{References}

1. Feigin VL, et al. Global, regional, and country-specific lifetime risks of stroke, 1990 and 2016. N Engl J Med. 2018;379(25):2429-37.

2. Emberson J, et al. Effect of treatment delay, age, and stroke severity on the effects of intravenous thrombolysis with alteplase for acute ischaemic stroke: a meta-analysis of individual patient data from randomised trials. Lancet. 2014;384(9958):1929-35.

3. Merkler AE, et al. Safety outcomes after thrombolysis for acute ischemic stroke in patients with recent stroke. Stroke. 2017;48(8):2282-4.

4. Hasan TF, et al. Endovascular thrombectomy for acute ischemic stroke. Curr Cardiol Rep. 2019;21(10):112.

5. Gulati A, et al. A novel neuroregenerative approach using ET(B) receptor agonist, IRL-1620, to treat CNS disorders. Physiol Res. 2018;67(Suppl 1):S95-113.

6. Shi L, et al. A new era for stroke therapy: integrating neurovascular protection with optimal reperfusion. J Cereb Blood Flow Metab. 2018;38(12):2073-91.

7. Zhang ZG, Chopp M. Neurorestorative therapies for stroke: underlying mechanisms and translation to the clinic. Lancet Neurol. 2009;8(5):491-500.

8. Tuttolomondo A, et al. Neuron protection as a therapeutic target in acute ischemic stroke. Curr Top Med Chem. 2009;9(14):1317-34.

9. Ly JV, Zavala JA, Donnan GA. Neuroprotection and thrombolysis: combination therapy in acute ischaemic stroke. Expert Opin Pharmacother. 2006;7(12):1571-81.

10. Lampl Y, et al. Endothelin in cerebrospinal fluid and plasma of patients in the early stage of ischemic stroke. Stroke. 1997;28(10):1951-5.

11. Ziv I, et al. Increased plasma endothelin-1 in acute ischemic stroke. Stroke. 1992;23(7):1014-6.

12. Barone FC, et al. Selective antagonism of endothelin-A-receptors improves outcome in both head trauma and focal stroke in rat. $\mathrm{J}$ Cardiovasc Pharmacol. 2000;36(5 Suppl 1):S357-61.

13. Briyal S, Gulati A. Endothelin-A receptor antagonist BQ123 potentiates acetaminophen induced hypothermia and reduces infarction following focal cerebral ischemia in rats. Eur J Pharmacol. 2010;644(1-3):73-9.

14. Legos JJ, et al. SB 234551 selective ET(A) receptor antagonism: perfusion/diffusion MRI used to define treatable stroke model, time to treatment and mechanism of protection. Exp Neurol. 2008;212(1):53-62.

15. Tatlisumak T, et al. A novel endothelin antagonist, A-127722, attenuates ischemic lesion size in rats with temporary middle cerebral artery occlusion: a diffusion and perfusion MRI study. Stroke. 1998;29(4):850-7 ((discussion 857-8)).

16. Zhang RL, et al. Synergistic effect of an endothelin type A receptor antagonist, S-0139, with rtPA on the neuroprotection after embolic stroke. Stroke. 2008;39(10):2830-6.

17. Briyal S, Gulati A, Gupta YK. Effect of combination of endothelin receptor antagonist (TAK-044) and aspirin in middle cerebral artery occlusion model of acute ischemic stroke in rats. Methods Find Exp Clin Pharmacol. 2007;29(4):257-63.

18. Briyal S, Pant AB, Gupta YK. Protective effect of endothelin antagonist (TAK-044) on neuronal cell viability in in vitro oxygen-glucose deprivation model of stroke. Indian J Physiol Pharmacol. 2006;50(2):157-62.

19. Chuquet J, et al. Selective blockade of endothelin-B receptors exacerbates ischemic brain damage in the rat. Stroke. 2002;33(12):3019-25.

20. Ehrenreich H, et al. Endothelin B receptor-deficient rats as a subtraction model to study the cerebral endothelin system. Neuroscience. 1999;91(3):1067-75.

21. Puppala B, et al. Ontogeny of endothelin receptors in the brain, heart, and kidneys of neonatal rats. Brain Dev. 2015;37(2):206-15.

22. Leonard MG, et al. Selective endothelin-B receptor stimulation increases vascular endothelial growth factor in the rat brain during postnatal development. Drug Res (Stuttg). 2015;65(11):607-13.

23. Gulati A. Endothelin receptors, mitochondria and neurogenesis in cerebral ischemia. Curr Neuropharmacol. 2016;14(6):619-26.

24. Leonard MG, Gulati A. Endothelin B receptor agonist, IRL1620 , enhances angiogenesis and neurogenesis following cerebral ischemia in rats. Brain Res. 2013;1528:28-41.

25. Briyal S, et al. Anti-apoptotic activity of ET B receptor agonist, IRL-1620, protects neural cells in rats with cerebral ischemia. Scientific reports. 2019;9(1):1-13.

26. Koyama Y, et al. I.c.v administration of an endothelin ET(B) receptor agonist stimulates vascular endothelial growth factor-A production and activates vascular endothelial growth factor receptors in rat brain. Neuroscience. 2011;192:689-98.

27. Vidovic M, et al. Deficiency in endothelin receptor B reduces proliferation of neuronal progenitors and increases apoptosis in postnatal rat cerebellum. Cell Mol Neurobiol. 2008;28(8):1129-38.

28. Druckenbrod NR, et al. Targeting of endothelin receptor-B to the neural crest. Genesis. 2008;46(8):396-400.

29. Leonard MG, Briyal S, Gulati A. Endothelin B receptor agonist, IRL-1620, reduces neurological damage following permanent middle cerebral artery occlusion in rats. Brain Res. 2011;1420:48-58.

30. Leonard MG, Briyal S, Gulati A. Endothelin B receptor agonist, IRL-1620, provides long-term neuroprotection in cerebral ischemia in rats. Brain Res. 2012;1464:14-23.

31. Kaesmacher J, et al. Direct mechanical thrombectomy in tPAineligible and -eligible patients versus the bridging approach: a meta-analysis. J Neurointerv Surg. 2019;11(1):20-7.

32. Pena ID, et al. Strategies to extend thrombolytic time window for ischemic stroke treatment: an unmet clinical need. J Stroke. 2017;19(1):50-60.

33. Kalogeris T, et al. Cell biology of ischemia/reperfusion injury. Int Rev Cell Mol Biol. 2012;298:229-317.

34. Bernal A, Arranz L. Nestin-expressing progenitor cells: function, identity and therapeutic implications. Cell Mol Life Sci. 2018;75(12):2177-95.

35. Shi $\mathrm{H}$, et al. Nestin expression defines both glial and neuronal progenitors in postnatal sympathetic ganglia. J Comp Neurol. 2008;508(6):867-78.

36. Barkho BZ, Zhao X. Adult neural stem cells: response to stroke injury and potential for therapeutic applications. Curr Stem Cell Res Ther. 2011;6(4):327-38.

37. Chan SJ, et al. Vascular endothelial growth factor 165-binding heparan sulfate promotes functional recovery from cerebral ischemia. Stroke. 2020:STROKEAHA119025304.

38. Molbay M, et al. Human placental trophoblast progenitor cells (hTPCs) promote angiogenesis and neurogenesis after focal cerebral ischemia in rats. Int J Neurosci. 2020;1-11. https://doi. org/10.1080/00207454.2020.1807978 
39. Banerjee $\mathrm{S}$, et al. Intra-arterial immunoselected CD34+ stem cells for acute ischemic stroke. Stem Cells Transl Med. 2014;3(11):1322-30.

40. Levy ML, et al. Phase I/II study of safety and preliminary efficacy of intravenous allogeneic mesenchymal stem cells in chronic stroke. Stroke. 2019;50(10):2835-41.

41. Ranjan AK, et al. Sovateltide (IRL-1620) affects neuronal progenitors and prevents cerebral tissue damage after ischemic stroke. Can J Physiol Pharmacol. 2020;98(9):659-66.

42. Ranjan AK, Briyal S, Gulati A. Sovateltide (IRL-1620) activates neuronal differentiation and prevents mitochondrial dysfunction in adult mammalian brains following stroke. Sci Rep. 2020;10(1):12737.

43. Dembowski C, et al. Phenotype, intestinal morphology, and survival of homozygous and heterozygous endothelin B receptordeficient (spotting lethal) rats. J Pediatr Surg. 2000;35(3):480-8.

44. Ehrenreich $\mathrm{H}$, et al. Endothelin $\mathrm{b}$ receptor deficiency is associated with an increased rate of neuronal apoptosis in the dentate gyrus. Neuroscience. 2000;95(4):993-1001.

45. Baynash AG, et al. Interaction of endothelin-3 with endothelin-B receptor is essential for development of epidermal melanocytes and enteric neurons. Cell. 1994;79(7):1277-85.

46. Riechers CC, et al. Endothelin B receptor deficient transgenic rescue rats: a rescue phenomenon in the brain. Neuroscience. 2004;124(4):719-23.

47. Brand $\mathrm{M}$, et al. Ontogeny of endothelins- 1 and -3 , their receptors, and endothelin converting enzyme- 1 in the early human embryo. J Clin Investig. 1998;101(3):549-59.

48. Shin MK, et al. The temporal requirement for endothelin receptor-B signalling during neural crest development. Nature. 1999;402(6761):496-501.

49. Kedzierski RM, Yanagisawa M. Endothelin system: the doubleedged sword in health and disease. Annu Rev Pharmacol Toxicol. 2001;41:851-76.

50. Briyal S, Lavhale MS, Gulati A. Repeated administration of centhaquin to pregnant rats did not affect postnatal development and expression of endothelin receptors in the brain, heart or kidney of pups. Arzneimittelforschung. 2012;62(12):670-6.

51. Heerspink HJL, et al. Atrasentan and renal events in patients with type 2 diabetes and chronic kidney disease (SONAR): a double-blind, randomised, placebo-controlled trial. Lancet. 2019;393(10184):1937-47.

52. Amann K, et al. Special characteristics of atherosclerosis in chronic renal failure. Clin Nephrol. 2003;60(Suppl 1):S13-21.

53. Vercauteren M, et al. Endothelin ETA receptor blockade, by activating ETB receptors, increases vascular permeability and induces exaggerated fluid retention. J Pharmacol Exp Ther. 2017;361(2):322-33.

54. Schilling L, et al. Cerebrovascular effects of endothelin-3: modulation of contraction by nitric oxide is independent of endothelin B receptor activation. Neurol Res. 1996;18(3):281-5.

55. Reddy G, et al. Toxicokinetic evaluation of IRL-1620 in a 4-week toxicology study in rats. In: The tenth international conference on endothelin 2007: Bergamo, Italy.

56. Tolcher A, et al. A phase I, open label, ascending dose study of the safety, tolerability, pharmacokinetics and pharmacodynamics of the endothelin B agonist, SPI-1620, in patients with recurrent or progressive carcinoma in the twelfth international conference on endothelin. 2011. University of Cambridge: British Pharmacological Society.

57. Archer CR, et al. Endothelin-1 promotes hypertrophic remodelling of cardiac myocytes by activating sustained signalling and transcription downstream of endothelin type A receptors. Cell Signal. 2017;36:240-54.

58. Bremnes $\mathrm{T}$, et al. Regulation and intracellular trafficking pathways of the endothelin receptors. J Biol Chem. 2000;275(23):17596-604.

59. Chun M, et al. Endothelin-induced endocytosis of cell surface ETA receptors. Endothelin remains intact and bound to the ETA receptor. J Biol Chem. 1995;270(18):10855-60.

60. National Institute of Neurological D, P.A.S.S.G. Stroke rt. Tissue plasminogen activator for acute ischemic stroke. N Engl J Med. 1995;333(24):1581-7.

61. Gargano JW, Reeves MJ, I. Paul Coverdell National Acute Stroke Registry Michigan Prototype. Sex differences in stroke recovery and stroke-specific quality of life: results from a statewide stroke registry. Stroke. 2007;38(9):2541-8.

62. Cifuentes EG, et al. Neuroprotective effect of IRL-1620, an endothelin $\mathrm{B}$ receptor agonist, on a pediatric rat model of middle cerebral artery occlusion. Front Pediatr. 2018;6:310.

\section{Affiliations}

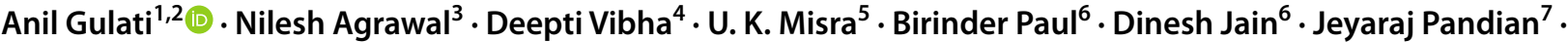 Rupam Borgohain ${ }^{8}$}

\section{Anil Gulati}

agulat@midwestern.edu; anil.gulati@pharmazz.com

1 Pharmazz, Inc., 50 West 75th Street, Suite 105, Willowbrook, IL 60527, USA

2 Midwestern University, Downers Grove, IL, USA

3 New Era Hospital, Nagpur, India

4 All India Inst of Medical Sciences, New Delhi, India
5 Sanjay Gandhi Postgraduate Institute of Medical Sciences, Lucknow, India

6 Dayanand Medical College, Ludhiana, India

7 Christian Medical College, Ludhiana, India

Nizam's Institute of Medical Sciences, Hyderabad, India 